\title{
PROSPECTS OF DAIRY FARMING AND ALLIED ENTREPRENEURSHIP: A BLESSING FOR POOR IN RURAL INDIA
}

\author{
Nizamuddin Khan ${ }^{1}$, Ashish Kumar Parashari ${ }^{2}$ and Mohd. Sadiq Salman ${ }^{3}$ \\ ${ }^{1}$ Professor Department of Geography, Aligarh Muslim University, Aligarh, India. \\ Email: nizamuddin_khan@rediffmail.com \\ ${ }^{2}$ Research Assistant, Department of Geography, Aligarh Muslim University, Aligarh, India \\ Email: amu.ashish@gmail.com \\ ${ }^{3}$ Guest Faculty, Department of Geography, Jamia Millia Islamia, New Delhi, India \\ Corresponding author Email: msadiqsalman@gmail.com
}

\begin{abstract}
India is the largest producer of milk globally employing 18 million people. Milk Production and marketing is still traditional and 60 percent of milk is transacted through unorganized sectors. The study aims to understand pattern of marketing of milk and its derived products, estimate the employment generated and exploring and assessing the potential of dairy development in the country. The study is based upon primary data collected from sampled villages of an underprivileged district of the Uttar Pradesh, the largest milk producer state of the country. A steep rise in dairy farming since last decade is found due to increase demand and improved remunerations and marketing opportunities. The allied activities are providing entrepreneurial opportunities to farmers, labourers and women on large scale. This gives enhanced household income promoting self-reliance and better economic conditions. This model of dairy farming can be applied in whole country to ensure better livelihoods for poor in India.
\end{abstract}

Key words: Dairy Farming, Employment, Livelihood, Livestock, Sustainable Development

\section{Introduction}

Dairy farming is one of the important agricultural systems of world. Most of developed countries of Europe, Australia, North America, South America and some from Asia practiced dairy farming as commercial business on very extensive scale. Most of extensive grassland especially in temperate regime rears cow for milk and beef separately. They are designated as milch and beef cattle. One third of geographical area and $1 / 4^{\text {th }}$ of world's population; mainly, small and marginal farmers have been endorsed for livestock husbandry and production of dairy and its derived products (Rangnekar D.V. 2006; Rama et.al.2005; Taneja V.K. 2008 \& Khan N. \& Parashari A.K. 2019). There are 125.34 million (2019) heads of dairy animals, including cows and buffalo in India. A large number of workers are associated directly with some processing activities as production of dry milk powder, paneer, cheese, butter, sweets, tea stalls, transportation and distribution.

Dairy farming has been practiced in India as an auxiliary activity to cropping system in the form of subsistence nature at a large scale. Some big companies managed by either private or cooperative societies, though in less number operate exclusive dairy farming system. Of the total milk production in India, about 48 percent milk is either consumed at the producer level or sold to non-producers in the rural area. The balance 52 percent of the milk is marketable surplus available for sale to consumers in urban areas. Out of marketable surplus it is estimated that about 40 percent of the milk sold is handled by the 
organized sector (i.e. 20 percent each by Cooperative \& Private Dairies) and the remaining 60 percent by the unorganized sector. 80 percent production, processing and distribution are performed by individual farmers in much unorganized way which includes door to door delivery, small market channel i.e. farmers- village traders and consumer (National Action Plan for Dairy Development-Vision 2022, 2018). About 16.6 million farmers have been brought under the ambit of about 1, 85,903 village level Dairy Cooperatite Societies (DCS) up to March 2018. (National Dairy Development Board, 2019) Despite the slump in world market and better procurement prices by dairy cooperatives along with decrease in procurement volume by major private players led to increase in milk collection by the dairy cooperatives by about 11 percent. The dairy cooperatives have procured daily average of milk about 475.6 lakh $\mathrm{kg}$ per day during 2017-18. Traditional contract dairy farming, in which the big players like sweet makers, milk traders in urban areas and milk processing units mortgage the farmers in different villages and provide them capital for purchasing animals and the price of milk is fixed, usually lower than open market price, at the time of final agreement of contact. India is the largest producer of milk since 1998 and production reached from 75.40 million tonnes in 1998to 187 million tonnes in 2019. The country has also improved per capita availability of milk from 210 grams / day in 1998-99 to 394 gram/day in 2018-19. It shared 26 percent to agriculture GDP of the country and employ millions of marginal and small farmers in different ways. It is a largest crop in term of money value which is more than total revenue earned from combined wheat and rice production in the country. Milk and milk products contributed more than 20.60 percent of the combined output of paddy, wheat and pulses in 2017(Parida, Y \& Yadav D. 2020) Dairying has become an important secondary source of income for millions of rural families and has assumed the most important role in providing employment and income generating opportunities particularly for marginal and women farmers (Ramphal O. 2016; Khan, N 2018). Most of the milk is produced by animals reared by small, marginal farmers and landless labours. Twenty-five percent of Indian farmers, mainly marginal with less than half hectares of land are involved in dairy farming in the country recently. The farmers are attached with cooperative societies for sale of their saleable milk. 16.60 million Farmers have been brought under registration of 185903 dairy cooperative society (DCS). As on 31.03.2018, the total number of women in dairy cooperatives across the country was 4.9 million including 32,092 women DCS which is 29.5 percent of total farmers (Animal Husbandry Statistics 2019)

The dairy development in term of milk production witnessed regional variation in response to geographical size, population, nature and stages of agricultural development and degree of demand for livestock derived products i.e. milk and meat as well as government policies and incentives to the farmers. The states like Uttar Pradesh (30.50 million tonnes), Rajasthan (23.63 million tonnes), Madhya Pradesh (15.91 million tonnes), Andhra Pradesh (15.04 million tonnes), Gujarat (14.49 million) and Punjab (12,60 million tonnes) are 5 top most milk producing states in India during 2018-19 financial year. The urban surrounding or peri urban has rather higher concentration for milk production as compared to interior village location, on account of a bumper demand for liquid milk and dairy derived products in fast growing urbanization and urban population (Khan N. \& Iqubal M.A. 2008; Khan N. et al. 2012). Localization of dairy processing units of large scale in this areas are also another acting player of occurrence of hot spot of dairy farming and production in urban area. Such urban oriented concentration of dairy production witnessed a historical fact that the first dairy or cattle colony was established in Allahabad during preindependence period for milk supply to army (Agriculture Skill Council of India 2016). Dairy processing plants were established in urban centres like Calcutta, Madras (Chennai), Mumbai rather than in milk shed or milk producing rural areas even after independence which discouraged rural dairy system development. This trend of development of urban oriented dairy farming has been observed to deviate towards far villages due to increasing urban land price, pollution issues (Khan N. and Salman M.S. 2014). Fodder crisis and development of fast urban rural transport linkage and fast and refrigerated transport means 
enabled the milk producers to sell their milk surplus in town and cities. Scaling up of this sector of livestock farming from subsistence to commercial and industrial nature resulted in socio economic and political dynamics in dairy farming structure in the country. Private capital investment in dairy sector from national and multinational companies tends to increase in the country but again nearby metropolitan cities like Delhi, Bengaluru, Mumbai, Chandigarh and Calcutta. Being a potential sector for generation of employment especially in rural areas as well as to enhance the farmers' income in addition to earned from cropping system, government of India looked it one of important innovative tool for doubling the farmers' income and remove the poverty from rural areas (Singh R.S. \& Shukla N. S 2017; Khan, N. et.al 2014; Khan N. \& lqbal M.A. 2009).

The growth and development of dairy in India took place in a sequential efforts of the government in both during pre and post-independence period. History of dairy development in India can be divided into two distinct phases: pre- and post-Operation Flood. The Defence Department under the British rule had established military dairy farms to ensure the supply of milk and butter to the colonial army. The first of these farms was set up in Allahabad in 1913, followed by Bangalore, Ooty and Karnal. These farms were well maintained and used improved milch animals. The onset of the Second World War gave momentum to private dairies with some modernized processing facilities. In the metros of the then Bombay, Calcutta, Madras and Delhi, and some large towns, processed milk, table butter and ice-cream were available, though on a limited scale (Kurein V. 2000; Mathur B.N. 2000; Kumar S.S. et.al. 2012).

The dairy farming sector drawn the special attention of the planners since the independence and it achieved success and amelioration and breakthrough during different plan periods adopted by country. Operation flood I, II \& III had been important dairy development strategies, run with international collaboration aided by World Bank. The Cooperative movement/ societies after establishment of National Dairy Development Board (NDDB) in 1965, under the effort of Dr. Berghese Kurien, the father of White Revolution, played a pivotal role in development of white revolution through linking rural dairy farmers with dairy processing units situated in urban areas. Therefore, in 1970 the government established a public-sector company, the Indian Dairy Corporation (IDC). The IDC was given responsibility for receiving the project's donated commodities, testing their quality, their storage and transfer to user dairies as well as receiving the dairies' payments. Thus the financial and promotional aspects were the responsibility of the IDC while the entire technical support for OFP was provided by NDDB. A large number of innovative schemes were introduced time to time by respective central and state governments for successive improvement in this sector of economy. Government of India is making efforts for strengthening infrastructure for production of quality milk, procurement, processing and marketing of milk and milk products through different Dairy Development Schemes. Some of them are as National Programme for Dairy Development (NPDD); National Dairy Plan (Phase-I); Dairy Entrepreneurship Development Scheme(DEDS); Support to Dairy Cooperatives and Dairy Processing and Infrastructure Development Fund (DIDF), National plan for Dairy Development, Vision 2022, are very much optimistic for dairy development and improvement of socioeconomic and health condition of dairy farmers. Ministry of Agriculture and Farmers' Welfare, Govt. of India, targeted to enhance the milk production to 300 million tonnes, marketable surplus to 180 million tonnes and milk bovine number to 116 million head during 2023-24 (Vision 2022-National Action Plan for Dairy Development 2018). The new agricultural trade policy enacted in June 2020, which tends to remove movement restriction and policy hindrance of old PMMC Act and enable farmers to sell their product anywhere in the country openly and private traders will be playing a crucial role in transaction of their marketable surplus at per-harvest price agreement through contract system. It will be also an encouraging effort to develop dairy farming in remote rural areas, generally, neglected in this sector due to inaccessibility to markets. Moreover, the country would emerge a top most country in dairy production and trade in future. Indian 
dairy market is expected to reach a value of Rs.18, 599 billion by 2023 exhibiting a CGAR of 12percent during 2018-23 (Bhatnagar J. 2018). The latest proposal of Govt. of India to encourage and promote private capital investment in establishing dairy and meat processing units ae well as feed grain production units in rural areas with a view to promote livestock husbandry and dairy farming in remote rural areas, would be an encouraging effort to multiply the incomes of the farmers in the country (Tekam D. et al. 2019).

Dairy farming has the potential of generation and development of sub sector or off dairy economic activities to add income to rural population and elevate their financial status. Meat industry, both at traditional and modernized, has been also developed in the country which slaughters male buffalo as well as retired / dry milk buffalo. It is one of the important sources of foreign exchange for national development through export to more than 50 countries of Asia and Africa continents. Establishment of new processing units for dairy products; packaging, preservation, cold chain logistics \& storage, fodder production farms, supply of feed in the form of concentrates and grain, credit and insurance and distribution and marketing are promising allied opportunities for investment and employment generation in the areas of dairy farming concentration (Bhanwala K.H. 2020)

Regional variation in dairy farming development is another feature in the country. Uttar Pradesh is the leading state not only in population and area but milk production and livestock number. She produced 30.50 million tonnes milk in 2019-20 due to having several advantages over the other states of the country due to having largest number female bovine including cows and buffalo (18percent), and largest number of vegetarian population who require dairy products for meeting their nutrition demand. As on 2017-18, U.P dairy industry is equipped with 6835 milk cooperative societies, 520 Bulk milk cooler units with capacity of 912000 litres (Uttar Pradesh Investor's Summit 2018). The dairy development in the state is also the function of degree of technological and innovative application, increasing intensity of cropping system and the degree of integration of livestock rearing with cropping system. Inter district and spatial variation in dairy farming performance and intensity as well as level of commercialization have been not uncommon features in the state. Western Uttar Pradesh, most of the districts, are highly developed in this sector of agriculture economy. Approximately $2 / 3^{\text {rd }}$ of farmers and even land less people are following dairy farming system, usually at small scale, in the form of livestock cropping integrated farming system which resulted in re utilization of cropping and livestock wastes for their effective and sustainable development reducing the production cost and enhancement of output revenue for the produce generated from this system (Khan N. 2018; Khan N. \& Parashari A.K. 2019). Contrary to it, eastern Uttar Pradesh (PURVANCHAL) especially Trans-Ghaghra region could not keep pace with national plan for dairy development during various five year plans, though first dairy colony was developed in Allahabad even during British India.

Before the adoption of green revolution and mechanization of agriculture during 1980 's, the region was practicing traditional cropping livestock farming system in which cattle (Oxen) were used for ploughing the land, transportation and thrashing the crops. Subsistence dairy system was also attached with most of the farmers. But the modernization, commercialization and mechanization of agriculture, though late as compared to Western Uttar Pradesh, resulted in two negative effects; leaving livestock rearing and release of agricultural labours, both household and hired. While in western U.P. dairy farming grew up after mechanization of agriculture and household labours especially from small and marginal operational holding absorbed in and crop residues in the form of dry fodder became valuable unlike eastern U.P. where fodder (locally known as bhusa) blown away in air through combined harvesters. The increasing demand of milk internally as well as externally could be met through development dairy farming in the villages of the area. Before the designing the strategy for dairying system in backward region, there is need to assess and evaluate the existing inherent potential of the area for development such economically promising agro based enterprise. Size of land holding, availability of 
labours, social structure of the farmers, existence of demand for liquid milk and derived products, vertical and horizontal market integration with processing units and direct milk consumers and distribution of cooperative societies as well as political support as subsidies, credit facilities and economic and social protection are valuable factors could be understood well. The literature available on the study of dairy development in India since the independence have been very much associated with macro or meso regions dealing with generalization of different policies, technological diffusion, national marketing and performance of big enterprises centres in urban environment. The exploration and assessment of potential of dairy development in remote and backward areas remained almost neglected.

\section{Objectives of Study}

The present study was undertaken to understand the socioeconomic profile of dairy farmers, pattern of milk marketing and its derived products, assessing the existing pattern of dairy allied activities and employment generated through dairy farming and allied sectors. Further, assessments of entrepreneurial potential of dairy development and its allied activities in the study area was also undertaken.

\section{Study Area}

The study area selected is a micro level region, Balrampur district from eastern Uttar Pradesh (figure I). It is located in trans Ghaghra region along Nepal border in the north and Gonda district in South. East and west side is demarcated by Siddhartha Nagar and Shrawasti district. Its boundary consists of Shivalik Range of Himalayas and the geographical boundary in the south is formed by River Kuwano. The extreme of Latitude and longitude are $27^{\circ} 30^{\prime}$ north and $82^{\circ} 11^{\prime}$ east. The geographical area of the district is 3,349 sq.km. The head quarter of district administration is at Balrampur town. From the administrative point of view, the district is divided into three tehsils namely Balrampur, Tulsipur and Utraula, and 9 development blocks. The district has 667 Gram Subhas and 1012 Revenue Villages along with 9 forest villages. There are 4 urban units in the district; two of them have the status of Municipal Board and two having the status of Town Panchayat.

The average rainfall of the district is $1150 \mathrm{~mm}$. The climate of this district is helpful for the health. The winter season from November to February is followed by the hot season from March to June and Monsoon season is from July to October. The wind blows mostly from east to west and west to east. The mostly rainfall nearly 90 percent becomes between middle of June to middle of October. The study area is primarily agricultural based region, cultivating chiefly Paddy, wheat, sugarcane, oil seeds, pulses and vegetables. The total gross cropped area and net sown area are360858 hectares and 216000 hectares respectively. Livestock including cattle, buffalo, goat and sheep are reared along with cropping system. More than 90 percent farmers are either marginal or small.

\section{Data Collection and Research Methodology}

The present research work is based on both primary and secondary sources of data. Secondary data were collected from published data banks of Ministry of Livestock, Dairying and Fisheries, Govt. Of India, U.P. Department of agriculture and Animal Husbandry, Department of Dairy Development, District Statistical Report, Balrampur, and from some reports, research papers on the study of Dairy Farming and Its Development. Primary source of data is the main component of the research. Being study area at micro level, data regarding dairy development and its allied activities were rarely available, Generation of data is the crucial challenge and constraints for researchers to achieve the above objectives. For this purpose, nine villages, one from each block, have chosen on the basis of population size. The villages selected for field survey were having population between 3000 to 6000 persons (Fig.I). One hundred households were selected from each village on the basis of randomly stratified sampling. Thus, total 900 households were selected from 
different landholding categories. The head of the household was interviewed on different issues of dairy farming and data was collected with the help of a well framed questionnaire.

Figure 01: Location of Balrampur District in Uttar Pradesh, India (2019)

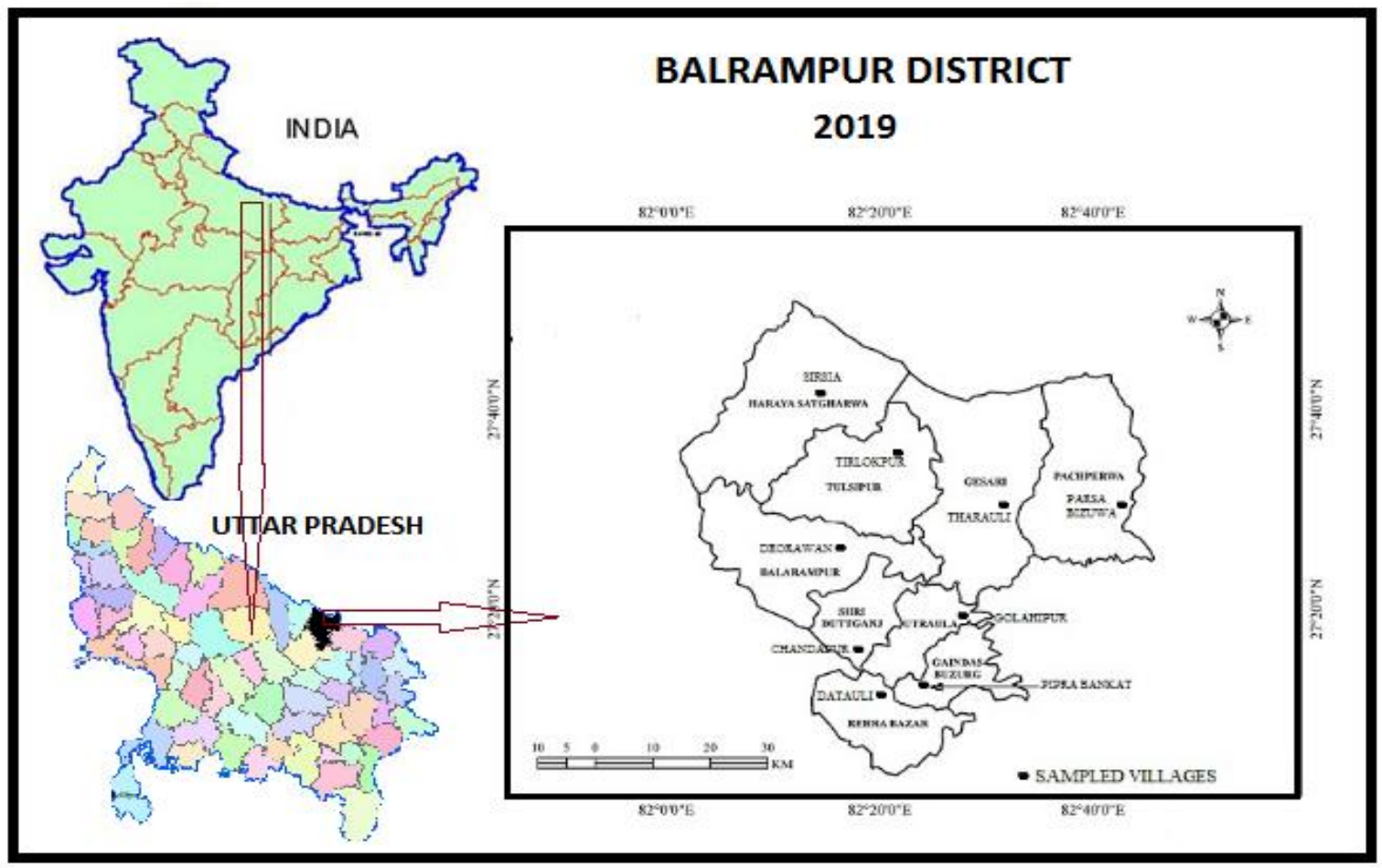

\section{Dairy Farming in Balrampur District:}

The livestock husbandry is not well developed in the study area. The total number of livestock, according to 2019 census is 226303 heads buffalo, 197746 cattle and 270790 goats. These important species reared by farmers as mainly household economic activity along with cropping system, described as mixed farming. It shows a regional variation from block to block depending upon geographical and socioeconomic profile of the area. The southern blocks of Rehra bazar and Gedas buzurg exhibited lower number as compared to Tulsipur, Gesadi and Pachpadwa blocks characterised with largest livestock number (table 01).

Table 01: Livestock Number in Balrampur District 2019

\begin{tabular}{|c|l|c|c|c|c|}
\hline$\#$ & \multicolumn{1}{|c|}{ Blocks } & Cattle & Buffalo & Goat & Total \\
\hline 1 & Harnaya Satgharva & 28138 & 29100 & 28727 & 85965 \\
\hline 2 & Balrampur & 29190 & 30468 & 29802 & 89460 \\
\hline 3 & Tulsipur & 16983 & 23638 & 30385 & 71006 \\
\hline 4 & Gainsadi & 24510 & 28521 & 35179 & 88210 \\
\hline 5 & Pachpadwa & 24746 & 28720 & 35392 & 88858 \\
\hline 6 & Shri Dutt Ganj & 18293 & 21405 & 27075 & 66773 \\
\hline 7 & Uttaraula & 20642 & 22132 & 27869 & 70643 \\
\hline 8 & Gendas Buzurg & 11092 & 16015 & 16008 & 43115 \\
\hline 9 & Rehra Bazaar & 21787 & 24624 & 28658 & 75069 \\
\hline & Total & $\mathbf{1 9 7 7 4 6}$ & $\mathbf{2 2 6 3 0 3}$ & $\mathbf{2 7 0 7 9 0}$ & $\mathbf{6 9 4 8 3 9}$ \\
& & $\mathbf{( 2 8 . 4 6 )}$ & $\mathbf{( 3 2 . 5 6 )}$ & $\mathbf{( 3 3 . 9 8 )}$ & $\mathbf{( 1 0 0 . 0 0 )}$ \\
\hline
\end{tabular}

Source: Calculated from the $20^{\text {th }}$ Livestock Census 2019 \& 2012.

Species and gender wise analysis of bovines indicates the domination of buffalo over cows as dairy animals during 2019. They are accounted for 59.40 percent and 43.48 percent out of total bovine livestock in the area respectively (table II). The comparative 
analysis of these species indicates that cow's number declined from 108845 heads to 76522 heads during 2012 to 2019 while she buffalo increased from 74334 to 99444 heads during same period. Mechanization of farming activities resulted in decline of male bovine as their utility reached to at minimum level. Ban on slaughtering of cattle and absence of meat factories in the area, which usually demand male buffalo as raw materials, are important causative factors of decline in their number. Most of them sold to outside traders and not kept by farmers for longer period to avoid extra burden of rearing cost on unproductive animals. Dairy Farming or milch livestock husbandry is the most important form of sub group of Indian agriculture. Dairying at subsistence and household level has been salient feature in the study area since antiquity. Commercial but still at household level and in traditional form, dairy farming started recently. The distribution of bovine milk livestock exhibited regional variation (Table 2). The terai region, a geographical area along Siwalik series, with ample pasture land and fallow land during rabi crop (OctoberDecember) season led to rearing of cows especially in larger number as compared to upland areas of southern part of Rehra, Gedas Buzurg, and utraula blocks of Utraula Tehsil. Cows are well reared where pasture lands are available. Their feeding through standing stall is rather less preferred. Cow rearing is practiced by all ethnic groups for milk purpose.

Table 02: Temporal Change in Milk Producing Livestock (Bovines) in Balrampur District (2012- 2019)

\begin{tabular}{|l|c|c|c|c|c|c|c|c|c|}
\hline \multirow{2}{*}{ Blocks } & \multicolumn{3}{|c|}{ Cows } & \multicolumn{3}{c|}{ Buffalo (She) } & \multicolumn{3}{c|}{ Total Bovines } \\
\cline { 2 - 10 } & $\mathbf{2 0 1 2}$ & $\mathbf{2 0 1 9}$ & $\begin{array}{c}\text { Change } \\
(\%)\end{array}$ & $\mathbf{2 0 1 2}$ & $\mathbf{2 0 1 9}$ & $\begin{array}{c}\text { Change } \\
(\%)\end{array}$ & $\mathbf{2 0 1 2}$ & $\mathbf{2 0 1 9}$ & $\begin{array}{c}\text { Change } \\
(\%)\end{array}$ \\
\hline $\begin{array}{l}\text { Harnaya } \\
\text { Satgharva }\end{array}$ & 15660 & 10241 & -34.69 & 9666 & 12254 & 29.57 & 25276 & 22495 & -11.0 \\
\hline Balrampur & 16687 & 11239 & -32.65 & 10424 & 14257 & 36.77 & 27111 & 25496 & -0.06 \\
\hline Tulsipur & 9718 & 7029 & -27.67 & 5901 & 8219 & 39.28 & 15619 & 15248 & -0.02 \\
\hline Gainsadi & 13292 & 9078 & -31.70 & 9427 & 12264 & 30.09 & 22719 & 21342 & -0.06 \\
\hline Pachpadwa & 14528 & 9045 & -37.74 & 9295 & 12779 & 34.25 & 23823 & 21824 & -0.08 \\
\hline Shri Dutt Ganj & 9712 & 7712 & -20.59 & 7229 & 9966 & 37.86 & 16941 & 17678 & 0.04 \\
\hline Uttaraula & 10931 & 8036 & -26.48 & 7477 & 9884 & 32.19 & 18408 & 17920 & -0.03 \\
\hline $\begin{array}{l}\text { Gendas } \\
\text { Buzurg }\end{array}$ & 6229 & 4723 & -24.18 & 6094 & 8236 & 35.15 & 12323 & 12959 & 0.05 \\
\hline Rehra Bazaar & 12088 & 9419 & -22.08 & 8821 & 11615 & 31.67 & 20909 & 21034 & 0.005 \\
\hline District & $\begin{array}{c}108845 \\
(59.42)\end{array}$ & $\begin{array}{c}76522 \\
(43.48)\end{array}$ & -29.70 & $\begin{array}{c}74334 \\
(40.58)\end{array}$ & $\begin{array}{c}99444 \\
(59.42)\end{array}$ & 33.78 & 183179 & 175966 & -0.04 \\
\hline
\end{tabular}

Source: Calculated from the livestock Census 2019

Buffalo share in dairy animal was less in the past but gradually increasing on account of commercialization and scaling up of dairy industry. Urban fringe areas witnessing high concentration of buffalo. Unlike cow, buffalo husbandry is rather more convenient in hot and rainy weather condition. Hundred percent feeding could be done through standing stalls. Productivity of milk per head is also high and price per $\mathrm{kg}$ is also higher than cow milk. Besides, unproductive, dry milch and male buffalo could be also sold in the market for meat purpose which adds a lucrative income to farmers unlike cattle sale is prohibited for meat purpose. Buffalo number is also higher in terai region as dairy farming at commercial scale is newly developing. Operational size of holding is bigger and the farmers have potential for dairy development on account of free availability of fodder, feed grains from their crops. The southern region showed slow development due to scarcity of labours in rural areas. Farmers of all categories follow mechanized agriculture and wasted dry fodder produced from residues of crops after harvesting after using combined harvesters on hire. Rural -urban migration is dominant and livestock husbandry is almost discouraged even by poor or land less farmers. Moreover, the dairy farming started due to increasing unemployment and government incentive for generation of livelihoods in rural areas with a view to enhance farmers 'income. Moreover, the dairy buffalo is, at present, higher in number in all blocks of the study area. 
Table 02 highlights the trends of change in dairy bovine number during last livestock Census period (2012 to 2019). Role of cows, though encouraged and political slogan, has been found to be declining. All blocks with exception of Shri Dutt Ganj and Gedas Buzurg, showed negative trends. It declined from 108845 heads to 103648 at a rate of 4.27 percent during same period. The major reason for this trend is extra burden of rearing expenditure on dry milch cows, male babies (Bachhara) and problem of disposable of unproductive and undesired cattle on account of prohibition of their sale in open markets by state and the central Government. Muslims are leaving the rearing of cows in the area due to increasing fear of tortures and undeclared punishment by police and miscreants in the name cow slaughter and smuggling. Buffalo have been replacing them and their number strides with positive trends exhibiting change from 74334 to 143354 heads during last six years with tune of 92.85 percent.

The livestock pressure with reference to grass cropped area and population is also one of important players of reflection of socio economic profile and state of livestock husbandry and dairy farming of an area. The study area witnessed 11.27 people served by one dairy animal and 1.22 hectare of land for one dairy animal during 2019. Spatial variation exists in both cases among the blocks (Table 03). The northern blocks in terai belt is reflecting rather more future prospect for dairy development as population and area per head is high as compared to southern region.

Table 03: Population- livestock and cropping Area - livestock Index (Ratio) in Balrampur District: 2019

\begin{tabular}{|c|l|c|c|c|c|c|}
\hline$\#$ & Block Name & Population & $\begin{array}{c}\text { Total Bovine } \\
\text { Milch } \\
\text { Livestock }\end{array}$ & $\begin{array}{c}\mathbf{P} / \mathbf{L} \\
\text { Index }\end{array}$ & $\begin{array}{c}\text { Cropped } \\
\text { Area(Hect.) }\end{array}$ & $\begin{array}{c}\mathbf{C} / \mathbf{L} \\
\text { Index }\end{array}$ \\
\hline 1 & $\begin{array}{l}\text { Harnaya } \\
\text { Satgharva }\end{array}$ & 268465 & 22495 & 11.93 & 32638 & 1.45 \\
\hline 2 & Balrampur & 311389 & 25496 & 12.21 & 34981 & 1.37 \\
\hline 3 & Tulsipur & 265435 & 15248 & 17.40 & 31117 & 2.04 \\
\hline 4 & Gainsadi & 247865 & 21342 & 11.61 & 35084 & 1.64 \\
\hline 5 & Pachpadwa & 218553 & 21824 & 10.01 & 26451 & 1,21 \\
\hline 6 & Shri Dutt Ganj & 164663 & 17678 & 9.31 & 14615 & 0.82 \\
\hline 7 & Uttaraula & 148620 & 17920 & 8.29 & 12492 & 0.67 \\
\hline 8 & Gendas Buzurg & 139672 & 12959 & 10.77 & 12882 & 0.99 \\
\hline 9 & Rehra Bazaar & 217742 & 21034 & 10.35 & 15977 & 0.75 \\
\hline & District & $\mathbf{1 9 8 2 4 0 4}$ & $\mathbf{1 7 5 9 6 6}$ & $\mathbf{1 1 . 2 7}$ & $\mathbf{2 1 6 2 3 7}$ & $\mathbf{1 . 2 2}$ \\
\hline
\end{tabular}

Source: District Statistical Report, 2019.

* $\mathrm{P} / \mathrm{L}$ Index = population per head bovine livestock, $\mathrm{C} / \mathrm{L}$ Index = cropped area per head bovine livestock

\section{Milk Production in Balrampur District}

Uttar Pradesh is the largest milk producer with 30.50 million tonnes in India. The state achieved this status due to highest number of milch animals as well as high intensity and development of dairy farming in western Uttar Pradesh where $2 / 3^{\text {rd }}$ of farmers are engaged in this activity following livestock cropping integrated farming system (Khan N. 2018). The study area Balrampur district lies in the Eastern part of the state and necessarily dairying activities could not well developed. Adoption of Green Revolution, though late during eighties of $20^{\text {th }}$ century, the mechanization and modernization of cropping system, led to release of agricultural labours, both household and hired, from agriculture. It resulted in mass rural urban migration of labours especially from land less and marginal farmer's groups to distant states like Maharashtra, Gujarat and Delhi. Livestock husbandry badly affected on account of induction of mechanical agricultural operation especially by tractors which were once performed by male cattle and buffalo. So the rearing of milch animals associated with draft animals has been neglected in the area in general and some milch animals like cows and buffalo reared by some special castes like Yadav, Ghosi, and 
Muslims etc. for traditional marketing purpose to cater needs in the same villages of their residence.

Recently the study area has been moving ahead towards dairy farming development like other part of the country and state. The demand for milk, locally as well as regional and national level, is continuously increasing in response to increasing trend of urbanization, improvement in disposable income and purchasing power on account of rising agriculture income from cash crops and flow of money from outside to migrant families and increasing health consciousness through high nutrition intake. Study revealed that milk production recorded a steady and continuous positive trend during last decade It improved from 107.13 thousand tonnes to 245.79 thousand tonnes during 2009-10 to 2019-20 at rate of 12 percent annually (Table 04 ). Regional variation could be also seen which is attributed to variation in milch livestock number and size of holdings. Teri region, the northern part of the district has high rate of milk production as compared to south region. The increasing number of buffalo replacing cows is another factor for increasing trend of milk production, usually former have higher yield per head than latter. Government dairy development schemes like Integrated Dairy Development Project (IDDP) Vision 2022-National Action for Dairy Development, entrepreneur Development scheme, Technical Input Facility to Milk Producers to Enhance Milk Production and strengthening reorganization and expansion of Milk Union/ Societies have been introduced time to time have now started to show better results in the region.

Table 04: Decadal Trend of Milk Production in Balrampur District (2009-2019)

\begin{tabular}{|c|c|c|c|}
\hline & & & Unit: 1000 tonnes \\
\hline Years & Production & Change & Growth (\% ) \\
\hline $2009-10$ & 107.13 & - & - \\
\hline $2010-11$ & 111.69 & 4.56 & 4.25 \\
\hline $2011-12$ & 139.33 & 27.43 & 24.55 \\
\hline $2012-13$ & 145.04 & 5.71 & 4.09 \\
\hline 2013-14 & 150.10 & 5.06 & 3.48 \\
\hline $2014-15$ & 155.76 & 5.66 & 3.77 \\
\hline $2915-16$ & 183.94 & 28.24 & 18.13 \\
\hline $2016-17$ & 200.56 & 16.62 & 9,03 \\
\hline $2017-18$ & 220.58 & 20.02 & 9.98 \\
\hline $2018-19$ & 235.89 & 15.30 & 6.93 \\
\hline $2019-20$ & 245.79 & 9.90 & 4.19 \\
\hline
\end{tabular}

Source: Department of Animal Husbandry and Dairying, Lucknow, Uttar Pradesh.

\section{Socio-economic Profile of Dairy Farmers}

The field survey of the sampled villages has revealed that dairy farming is one of the most important activities in the villages of India. Thus, people have livestock for their personal or commercial purposes. The table $\mathrm{V}$ shows that 35.67 percent of total 900 households. Thus, 321 households were found to be dairy farmers which varied from 29 in Chandpur to 45 in Trilokpur. The table VI gives the details of the landholding and caste structure of the dairy farmers. Dairy farming in study area is a caste oriented activity. The specific Yadav caste $(\mathrm{OBC})$ is known for rearing cows and buffalo for commercial milk production. Higher castes like Brahmins and Muslims also keep dairy livestock but for domestic consumption. The field survey and personal observation indicate social transformation and other castes also involve in dairy farming recently due to increasing commercialization of agriculture. Dairy farmers are socially structured into three categories as General / high castes (privileged group), Other Backward Castes (underprivileged group) and Scheduled castes/ Tribes (deprived caste). Study reveals that75.08 percent of dairy farmers in the sampled villages are from few castes i.e. Varma, Yadav, Nai, Dhunia, Kumhars from Other Backward Castes (OBC's). Scheduled castes rarely keep dairy animals and their participation is insignificant (0.62 percent) in the study area. High castes like Thakur, Brahmins, Pathan, Sheikh, 
Sayyed, Kayastha are also involved in dairy farming in the area. They participate and contribute up to 24.30 percent of total dairy farmers.

Table 05: Proportion (\%) of Dairy Farmers in Sampled Households (2019)

\begin{tabular}{|c|l|c|c|c|c|}
\hline$\#$ & Block Name & $\begin{array}{c}\text { Sampled } \\
\text { Villages }\end{array}$ & $\begin{array}{c}\text { Not engaged } \\
\text { in Dairy } \\
\text { Farming }\end{array}$ & $\begin{array}{c}\text { Dairy } \\
\text { Farmers }\end{array}$ & $\begin{array}{c}\text { Share Dairy } \\
\text { Farmers to Total } \\
\text { Farmers (\%) }\end{array}$ \\
\hline $\mathbf{1}$ & Harnaya Satgharva & Sirsia & 61 & 39 & 39 \\
\hline $\mathbf{2}$ & Balrampur & Deorawan & 59 & 41 & 41 \\
\hline $\mathbf{3}$ & Tulsipur & Tirlokpur & 55 & 45 & 45 \\
\hline $\mathbf{4}$ & Gesari & Tharauli & 64 & 36 & 36 \\
\hline $\mathbf{5}$ & Pachperwa & Parsa Bizuwa & 67 & 33 & 33 \\
\hline $\mathbf{6}$ & Shri Dutt Ganj & Chandapur & 71 & 29 & 29 \\
\hline $\mathbf{7}$ & Uttaraula & Golahipur & 73 & 27 & 27 \\
\hline $\mathbf{8}$ & Gainndas Buzurg & Pipra Bankat & 67 & 33 & 33 \\
\hline $\mathbf{9}$ & Rehra Bazaar & Datauli & 62 & 38 & 38 \\
\hline \multicolumn{2}{|r|}{ Total district } & & $\mathbf{5 7 9}$ & $\mathbf{3 2 1}$ & $\mathbf{3 5 . 6 7}$ \\
\hline
\end{tabular}

Source: Field Survey, 2019

Table 06: Landholding and Caste Structure of Dairy Farmers (2019)

\begin{tabular}{|c|c|c|c|c|c|c|c|}
\hline \multirow[b]{2}{*}{ Village } & \multicolumn{4}{|c|}{ Landholding Status ( $\mathrm{N}=321)$} & \multicolumn{3}{|c|}{ Caste Structure( $\mathrm{N}=321)$} \\
\hline & Landless & $\begin{array}{c}\text { Marginal } \\
\text { Farmers } \\
(>1 \\
\text { Hect. })\end{array}$ & $\begin{array}{c}\text { Small } \\
\text { Farmer } \\
(1-4 \text { Hect. })\end{array}$ & $\begin{array}{c}\text { Big } \\
\text { Farmer } \\
<4 \\
\text { Hect.) }\end{array}$ & $\begin{array}{l}\text { High Caste } \\
\text { (Privileged } \\
\text { group) }\end{array}$ & $\begin{array}{c}\text { Other } \\
\text { Backward } \\
\text { Class } \\
\text { (underprivile } \\
\text {-ged groups) }\end{array}$ & $\begin{array}{c}\text { Low Caste } \\
\text { (deprived } \\
\text { groups) }\end{array}$ \\
\hline Sirsia & 3 & 14 & 14 & 8 & 8 & 31 & 0 \\
\hline Deorawan & 2 & 21 & 9 & 9 & 12 & 28 & 1 \\
\hline Tirlokpur & 6 & 21 & 13 & 5 & 9 & 36 & 0 \\
\hline Tharauli & 2 & 15 & 12 & 7 & 7 & 29 & 0 \\
\hline $\begin{array}{l}\text { Parsa } \\
\text { Bizuwa }\end{array}$ & 0 & 13 & 11 & 9 & 5 & 27 & 1 \\
\hline Chandapur & 2 & 7 & 14 & 6 & 9 & 20 & 0 \\
\hline Golahipur & 2 & 2 & 19 & 4 & 11 & 16 & 0 \\
\hline $\begin{array}{l}\text { Pipra } \\
\text { Bankat }\end{array}$ & 3 & 15 & 8 & 7 & 7 & 26 & 0 \\
\hline Datauli & 1 & 22 & 9 & 6 & 10 & 28 & 0 \\
\hline Total & $\begin{array}{c}21 \\
(6.54)\end{array}$ & $\begin{array}{c}130 \\
(40.50)\end{array}$ & $\begin{array}{c}109 \\
(33.96)\end{array}$ & $\begin{array}{c}61 \\
(19.00)\end{array}$ & $\begin{array}{c}78 \\
(24.30)\end{array}$ & $\begin{array}{c}241 \\
(75.08)\end{array}$ & $\begin{array}{c}02 \\
(0.62)\end{array}$ \\
\hline
\end{tabular}

Source: Field Survey, 2019

Economic stratification, based on distribution of size of holdings, played pivotal role in development of dairy farmer's structure in the area. Landless, Marginal and small farmers with less than 4 hectares of land, are accounted for 81 percent of total dairy farmers. Big farmers (more than 4 hectares of land) shared only to 19 percent of dairy farmers, though generally they hold more than 50 percent of land of their village. Size of stock of dairy animals is very small, ranging 1-3 animals among poor farmers as compared to rich and high caste dairy farmers with 10-20 heads. The income per unit animal from milk sale is higher for marginal and small farmers due to low cost of production on account of using household labour and self-farm produced fodder and feed grains in the rearing operation. While the latter have to use hired labours for most of the dairy farming operation. Non farmers or landless people also follow the dairy farming, based on hired labours and purchased fodder. It is a form of exclusive dairy farming. Size of stock or number of animals kept by them is rather high more than five, sometimes reaches to hundred. They trade off the extra cost of production with increasing size of stock. Some private companies are also investing now in this sector. 


\section{Distribution and Marketing of Milk}

The share of milk utilized at domestic level was found to be 30.33 percent of total production. Thus, the remaining marketable surplus milk (69.67 percent) is transacted through various channels. Milk production is dominated by marginal and small farmers in the area thus 92.73 percent of marketable surplus is distributed through unorganized sector i.e. producer sellers, village trader, local assembly centres, milk processing units as sweet makers, paneer and curd processors etc. (table VII) .Organized sectors like cooperative societies, private or public dairy processing enterprises catch up only 7.27 percent of marketable surplus against to developed districts especially Western Uttar Pradesh, Punjab, Haryana and Gujarat where dairy cooperative societies have been very much active in assembling, marketing and manufacturing of dairy products. Dairy farmers irrespective of their assets, status, sale volume and socio-economic status generally prefer to sell their surplus through cooperatives and government agencies even they offer lower price compared to local traders (Kumar A. et. al. 2018; Chaturvedi B.K. 2013; Singh R.B.et.al 2018).

Table 07: Marketing of Milk (\%) through Various Agencies in Balrampur 2019

\begin{tabular}{|l|c|c|c|c|}
\hline Sampled Villages & Direct Sale & Milk Man & $\begin{array}{c}\text { Local } \\
\text { processing } \\
\text { Units }\end{array}$ & $\begin{array}{c}\text { Dairy } \\
\text { Cooperatives }\end{array}$ \\
\hline Sirisa & 53.33 & 16.67 & 30.00 & 0.00 \\
\hline Dewaran & 51.61 & 16.13 & 25.81 & 6.45 \\
\hline Tirlokpur & 48.28 & 20.69 & 20.69 & 10.34 \\
\hline Tharoli & 47.83 & 21.74 & 26.09 & 4.35 \\
\hline Parsa Bizuewa & 45.00 & 20.00 & 30.00 & 5.00 \\
\hline Chandapur & 44.44 & 11.11 & 33.33 & 11.11 \\
\hline Golahipur & 52.63 & 21.05 & 21.05 & 5.26 \\
\hline Pipra Bankat & 47.83 & 13.04 & 21.74 & 17.39 \\
\hline Datauli & 44.44 & 18.52 & 29.63 & 7.41 \\
\hline Total & $\mathbf{4 8 . 6 4}$ & $\mathbf{1 7 . 7 3}$ & $\mathbf{2 6 . 3 6}$ & $\mathbf{7 . 2 7}$ \\
\hline Sour: & & &
\end{tabular}

Source: Field Survey, 2019-20

Table 07 reveals that dairy farmers with small surplus less than $10 \mathrm{~kg}$ prefer to sell their surplus milk directly to rural consumers, receiving rather high price as compared to sell to organized sector. 48.64 percent is transacted in this way of direct marketing. Second preference of choice is controlled by tea stalls, halwais or sweet makers or small dairy processors. They are following traditional contract farming through offer of capital for purchasing animals and getting milk at lower price. This channel absorbs 26.60 percent of marketed surplus. Village traders' role is not satisfactory, dealing only with transaction of 17.73 percent of total milk transaction. Corporation or government and cooperative societies are little preferred by dairy farmers in study area due to unawareness about the benefit of these institutions on account of weak extension service regarding national and state dairy development schemes. Castes, income, stock size, volume of saleable milk, education, gender as well government attractive policies play very important role in varying preference of farmers to sell their milk marketed surplus (Kumar A. et.al. 2018).

The milk derived products i.e. ice cream, paneer, curd, butter, ghee, khowa and sweets are almost locally processed and distributed through small channels within the region. No processing units of national or state level are established either in private or public sector. Producer- consumer, producer-village trader- processing units-consumers, producer- cooperative society- consumer and producer are important milk and its derived product marketing channels prevailed in Balampur district. 


\section{Assessment of Dairy Allied Activities and Employment}

Dairy farming is one of the important sub system of agriculture economy in the country. It includes various operations i.e. rearing, feeding, washing, cleaning, milking, assembling, distribution, transportation and processing and marketing. Farmers use both household as well as hired labours for performing these operations. Mostly feeding, cleaning, collection of fodder, as well as grazing have been controlled by female members from poor and low socio economic group of farmers. These activities help in economic benefits and long term sustainability of the people employed resulting into their socioeconomic development (Khan N. et al. 2013) Different operations are continuously done for eight hours but in few hours of day. Number of employment is calculated on the basis of eight hours for one person. The estimation of employment from dairy activities and allied activities is made separately and finally combined to assess total employment generation from dairy farming and allied activities in Balrampur district. Table 08 indicates the number of employment from dairy allied activities i.e. marketing, fodder selling, sweet, paneer, cheese and guard making, dung cake making and dairy product processing as well as meat processing and selling. The study reveals that in the sampled villages 297 people are getting employment in allied activities of dairy farming. These employed people are generally those of dairy farmer households who are doing supplementary and complimentary activities to support dairy farming in the study area.

Table 08: Pattern of Dairy Derived Allied Activities and Employment in Sampled Villages (2019)

\begin{tabular}{|l|c|c|c|c|c|c|c|}
\hline Sampled village & $\begin{array}{c}\text { Mark- } \\
\text { eting }\end{array}$ & $\begin{array}{c}\text { Fodder } \\
\text { seller }\end{array}$ & $\begin{array}{c}\text { Sweet } \\
\text { Makers/ } \\
\text { Curd, } \\
\text { paneer etc. }\end{array}$ & $\begin{array}{c}\text { Assembler } \\
\text { (Milk) }\end{array}$ & $\begin{array}{c}\text { Dung } \\
\text { cake }\end{array}$ & $\begin{array}{c}\text { Meat } \\
\text { seller }\end{array}$ & Total \\
\hline Sirisa & 06 & 03 & 02 & 0 & 10 & 0 & 21 \\
\hline Dewaran & 08 & 06 & 03 & 0 & 15 & 0 & 32 \\
\hline Tirlokpur & 09 & 07 & 03 & 02 & 17 & 02 & 40 \\
\hline Tharoli & 10 & 08 & 04 & 02 & 20 & 0 & 44 \\
\hline Parsa Bizuwa & 07 & 05 & 0 & 03 & 12 & 03 & 30 \\
\hline Chandapur & 05 & 05 & 02 & 0 & 15 & 0 & 27 \\
\hline Golahipur & 10 & 07 & 01 & 01 & 20 & 02 & 41 \\
\hline Pipra Bankat & 06 & 04 & 02 & 01 & 10 & 01 & 34 \\
\hline Datauli & 06 & 05 & 02 & 02 & 10 & 03 & 28 \\
\hline $\begin{array}{l}\text { Total Sampled } \\
\text { Villages }\end{array}$ & $\mathbf{6 7}$ & $\mathbf{5 0}$ & $\mathbf{1 9}$ & $\mathbf{1 1}$ & $\mathbf{1 2 9}$ & $\mathbf{1 1}$ & $\mathbf{2 9 7}$ \\
\hline $\begin{array}{l}\text { Sampled Villages } \\
\text { (Average) }\end{array}$ & $\mathbf{7 . 4 4}$ & $\mathbf{5 . 5 6}$ & $\mathbf{2 . 1 1}$ & $\mathbf{1 . 2 2}$ & $\mathbf{1 4 . 3 3}$ & $\mathbf{1 . 2 2}$ & $\mathbf{3 3 . 0 0}$ \\
\hline
\end{tabular}

Source: Estimated on the basis of field survey, 2019-20.

The above discussion reveals that 35.67 of rural households are engaged in dairy farming. Thus, in the sampled villages it was observed dairy farming is an employment avenue to different allied activities for the rural population. The assessment of employment in this sector on the same scale can be calculated for all the villages in a particular block, thereby total employment in dairy farming and allied activities can be easily assessed in the district. This has been estimated in table 09. Which reveals that the district has employed 31803 persons in dairy allied economic activities during 2019. Regional variation is observed from one block to another on account of differences in population size, socioeconomic profile, ethnic composition and size of land holdings of farmers. It ranges between 1904 persons in Gedas Buzurg and 6028 persons in Gaisadi block. The northern blocks of Balrampur, Gainsadi, Pachperwa, Tulsipur and Balrampur exhibited higher number of employed persons in dairy allied activities as shown in same table. The southern region, especially Utraula, Gedas Buzurg and Rehra Bazar block shows rather lesser number of employment in aforesaid activities. 
Moreover, dairy farming exclusively, appears to employ approximately 1, 43,756 persons in the district, on an average of two persons from each dairy farmer's household. Highest number of dairy farming generated employed persons is 33714 in Pachpedwa block while the Gedas Buzurg witnessed least number of 3614 persons (Table 09). Northern blocks further represent higher rate of employment through dairy farming as compared to southern one as shown in same table. Total employment generated by dairy farming and its allied activities is about 8 percent of total population (2011). Study revealed that this sector of agricultural economy plays an important role in dealing with rural unemployment resulted in after mechanization of cropping system and reducing of size of holding successively year after in the country in general and particular in the study area.

Table 09: Estimated Employment through Dairy Farming and Its Allied Activities

\begin{tabular}{|l|c|c|c|c|c|}
\hline \multicolumn{1}{|c|}{ Blocks } & $\begin{array}{c}\text { Total } \\
\text { Farmers } \\
\text { Households }\end{array}$ & $\begin{array}{c}\text { Dairy } \\
\text { Farmers } \\
\text { Households }\end{array}$ & $\begin{array}{c}\text { Persons } \\
\text { Employed in } \\
\text { Dairy } \\
\text { Farming }\end{array}$ & $\begin{array}{c}\text { Persons } \\
\text { Employed in } \\
\text { Dairy Allied } \\
\text { Activities }\end{array}$ & $\begin{array}{c}\text { Total } \\
\text { Persons } \\
\text { Employed }\end{array}$ \\
\hline $\begin{array}{l}\text { Harnaya } \\
\text { Satdharwa }\end{array}$ & 33837 & 11277 & 22554 & 2709 & $\mathbf{2 5 2 6 8}$ \\
\hline Balrampur & 36684 & 12226 & 30556 & 4288 & $\mathbf{3 4 8 4 4}$ \\
\hline Tulsipur & 24449 & 7721 & 15442 & 4240 & $\mathbf{1 9 6 8 2}$ \\
\hline Gainsadi & 30476 & 11611 & 27927 & 6028 & $\mathbf{3 3 9 5 5}$ \\
\hline Pachpedwa & 29968 & 11238 & 33714 & 3990 & $\mathbf{3 3 7 0 4}$ \\
\hline Shri Dutt Ganj & 17598 & 3852 & 4000 & 2158 & $\mathbf{6 1 5 8}$ \\
\hline Utraula & 20465 & 6139 & 12278 & 3808 & $\mathbf{1 6 0 8 6}$ \\
\hline Gedas Buzurg & 9810 & 3614 & 3614 & 1904 & $\mathbf{5 5 0 8}$ \\
\hline Rehra Bazar & 22932 & 7643 & 15286 & 2688 & $\mathbf{1 7 9 7 4}$ \\
\hline Total District & $\mathbf{2 2 6 4 5 8}$ & $\mathbf{7 1 8 7 8}$ & $\mathbf{1 4 3 7 5 6}$ & $\mathbf{3 1 8 0 3}$ & $\mathbf{1 9 3 1 7 9}$ \\
\hline
\end{tabular}

Source: Calculated on basis of estimates obtained from field survey (table 08), 2019

\section{Dairy Farming and Potential Entrepreneurial prospects in future}

Dairy farming is expected to have tremendous opportunities for development of farmers, labourers and women and in total rural transformation (Khan N. 2018; Khan N. et.al 2014; The Hindu 2019) in the country. Quantification of opportunities and potentials is a herculean task. Data on different issues are not available. Field survey through the interview of respondents is the only solution of the present problems. The perception or thinking of 900 sampled households from 9 villages of 9 development blocks of district Balrampur has been used for assessment of different opportunities of dairy farming development in future. Scaling up and industrialization of dairy farming has been taking place after liberalization of agricultural trade. Small stock size of milch livestock per dairy farmer's household is not profitable due to high cost of production. Contrary to this big size of stock appears rather more profitable as the production cost is spread over larger number of livestock rearing and output return becomes rather more.

The perception of respondents shown in table $X$ indicates that dairy farming has a huge potential for scaling up to 10 livestock and even more. Further, the allied activities will also see an expansion in near future because of a mass perception that sector has a potential for entrepreneurial growth. The dynamics of dairy farming, in the discussed area, inevitably will generate and ameliorate different related opportunities / entrepreneurships like milk assembly centres, animal feed, concentrate and fodder selling units, dairy processing units' establishment, refrigerator transport facilitators, Fodder crop producers and dung cake/ wood and Verna compost bio fertilizers processors and bio gas units' enhancement (Hussain K.2019; Financial Express 2020; The Hindu 2019). Milk assembling units will score larger number to collect the milk surplus, with a tune of 25 to 50 percent change till the end of next decade as answered by 85 percent of respondents. Animal feed and fodder sellers would be also risen up by 50 percent as expected by 85 percent respondents. The waste of crop residues, which is blown out and burnt after harvest, would 
be procured and sold to livestock rearers in and out of villages. The income of farmers is expected to enhance after selling their by-products of crops. Similarly, the demand for green fodder crops is expected to increase from especially land less and marginal dairy farmers, poor in land for these crops. Private and public capital investment is required to establish dairy processing units' in backward areas of dairy farming like Balrampur of Uttar Pradesh. 80 percent of respondents are optimistic for establishment of such unit for manufacturing of ice cream, paneer, cheese, frozen packed milk and dry milk powder. The value addition process of dung, produced in huge quantum at rate at least $5 \mathrm{~kg}$. Per animal/ day, is another income enhancement opportunity for dairy farmers. Dung cake and dung woods are now produced and sold in the area at rate of 5 INR per $\mathrm{kg}$ and consumed for domestic fuels. Bio fertilizer from Verna compost process is one of high remunerative dairy by-products also reflects high expectation to the farmers to improve their income from animal husbandry especially dairy farming. Most of the respondents positively viewed for opportunity of development bio gas production in rural area and expect to increase by more than 50 percent rate in future. This opportunity indirectly will reduce extra expenditure paid for electricity and fire fuels or LPG for cooking purpose.

Table 10: Perception of Future of Dairy Development in Balrampur District (2019)

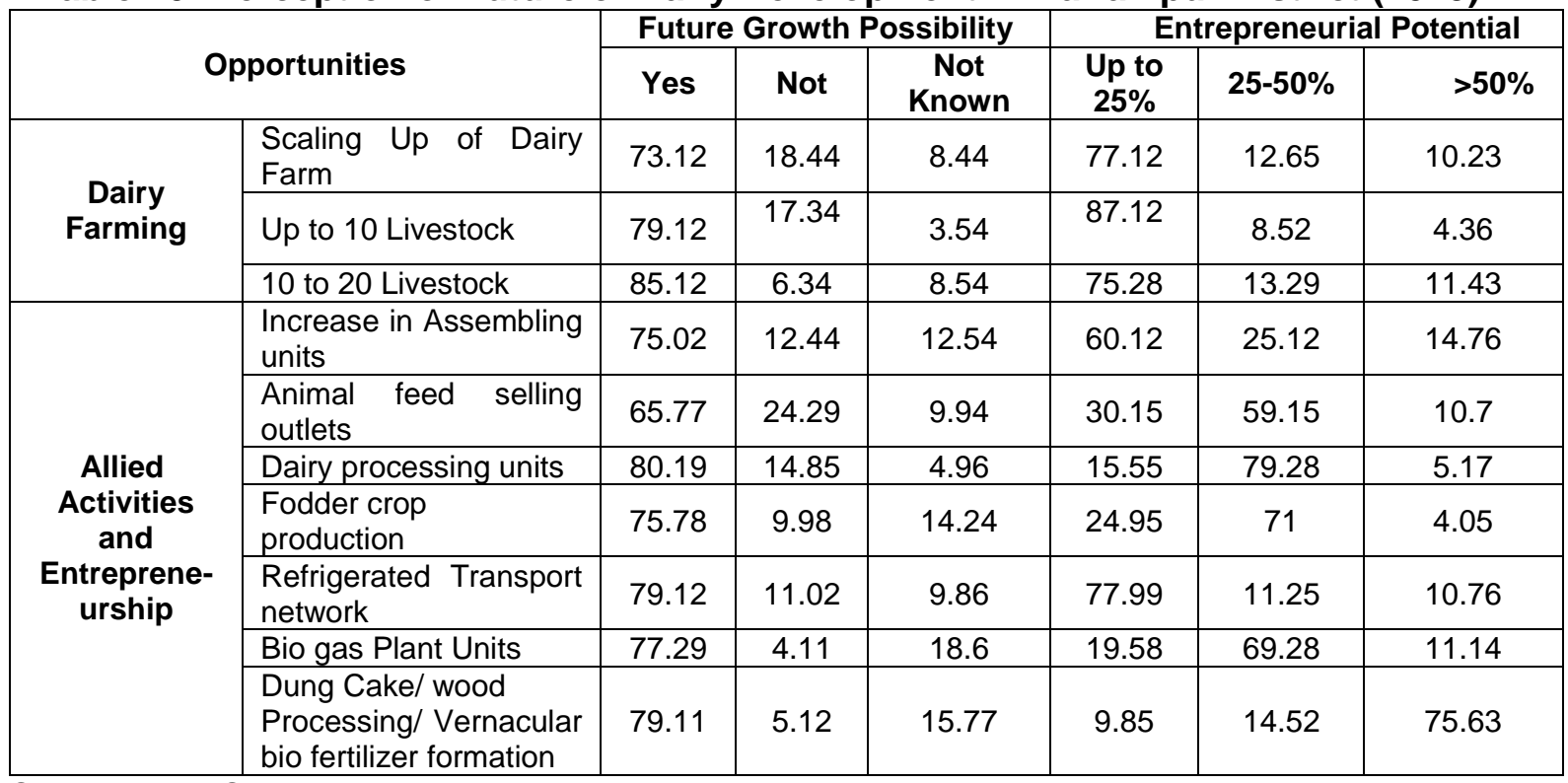

Source: Field Survey, 2019-20

\section{Conclusion}

The dairy farmers on an average in the area consume 30.33 percent of total milk production at their household level. The marketable surplus of milk is marketed usually in traditional ways, largely through unorganized sector. Thus, 92.73 percent of marketable surplus is distributed through unorganized sector i.e. producer sellers, village trader, local assembly centres, milk processing units as sweet makers, paneer and curd processors etc. Organised sector including cooperative societies, private processing units shares only 7.27 percent of marketable surplus. Direct marketing in which producers sell their surplus directly to consumers is the most remunerative and accounts for 48.64 percent of total marketed milk. Traditional contract dairy farming is also prevailed in which marketable surplus is sold to contractors like sweet makers, local traders etc. who provide capital for purchasing animals in advance and pay less price as compared to open price in the market.

There are numerous allied activities related to dairy farming in area under study. They include marketing, fodder selling, sweet, paneer, cheese and guard making, dung cake making and dairy product processing as well as meat processing and selling. The district has employed 31803 persons in dairy allied economic activities during 2019. Moreover, dairy farming exclusively, appears to employ approximately 1, 43,756 persons in the 
district, on an average of two persons from each dairy farmer's household. Thus the estimated employment generated, combined dairy farming and its allied activities is 193179 persons in 2019, sharing 8 percent of district total population. It is one of the most important source of development of employment and income and best tool for poverty alleviation and doubling of farmer's income as well as to achieve self-reliance in rural areas as advocated present Government of India during post COVID 19. Dairy farming is expected to have tremendous opportunities for development of farmers, labourers and women and in total rural transformation. Scaling up of farm size, opening of animal fodder and feed grain selling out lets, private capital investment in dairy product processing industries, development of refrigerated transport service to dairy farmers, Packaging, establishment of bio gas plants, preparation dung cake and bio fertilizer are new opportunities for employment generation, income enhancement of farmers, improvement in economic viability Indian farming and farmers and socio economic rural transformation as well as achieving rural self-reliance in the country in future.

Acknowledgement: Authors are very much obliged and thankful to IMPRESS, scheme, ICSSR, New Delhi. for providing fund under research scheme entitled Assessment of Potential of Dairy Farming and Its Allied Activities for Socio economic Development of Farmers in Devi Patan Region, Uttar Pradesh.

\section{References}

1. Agriculture Skill Council of India (2016). Facilitator Guide: Dairy Farmer/Entrepreneur, Agriculture Skill Council of India, Ministry of Skill and Entrepreneurship Development, Government of India.

2. Animal Husbandry Statistics (2019). Department of Animal Husbandry, Dairying, and Fisheries, Government of India.

3. Bhanwala K.H. (2020). How India can push its dairy cart ahead, $27^{\text {th }}$ May https://www.financialexpress.com/, retrieved on 20 July 2020.

4. Bhatnagar J. (2018). Dairy sector: Indian economy's milch cow, https://www.financialexpress.com/, retrieved on 20 July ,2020.

5. Chaturvedi, B.K (2013). Economic Viability of Milk Producing Units with Intervention of Marketing Strategy in Rural Areas of Uttar Pradesh, Journal of Agriculture and Veterinary Science, JOSR, Vol.5, pp.1-06.

6. District Statistical Magazine (2019). District Statistical Magazine Balrampur, Directorate of Statistics and Economics, Lucknow, Uttar Pradesh, India.

7. Financial Express (2020). How Dairy Co-operatives Have Showcased; A model for Realization of Atmanirbhar (Self Reliance) Bharat in Post Covid 19 Era, Financial Express, $15^{\text {th }}$ July 2020.

8. Hussain, K. (2019). Opportunity Cow Dung, Good Return, Daily News Paper, sat, July, 18, 2019.

9. Khan N. \& Salman M.S. (2014). Livestock Husbandry in Peri-urban Areas: Livestock Intensification, Livelihoods and Changing Farming Systems, Lambert Academic Publishing Company, Germany.

10. Khan N. Parashari A. and Salman M.S. (2014). Role of Dairy Co-Operatives in SocioEconomic Development of Dairy Farmers in Moradabad District: A Case Study, Research Forum: International Journal of Social Sciences, Volume-2, Issue-1, pp: 1-8.

11. Khan N., Salman M.S. and Rehman A. (2012). Dynamics and diversification of livelihood in urban fringe of Aligarh, city, U.P., India, REVIJA ZA GEOGRAFIJO-Journal for Geography, University of Maribor, SLOVENIA, Vo1.7 No.1

12. Khan N., Rehman A. and Salman M.S. (2013). Impact of Livestock rearing on the Socioeconomic Development in North India, Forum Geografic, University of Craiova, Department of Geography, ROMANIA, Vol.12, Issue I (June,2013), pp. 75-80.

13. Khan, N. \& Iqubal, M.A. (2008). Livestock Husbandry and Its Impact on Employment Generation in Aligarh District, U.P., African Journal of Livestock Extension, Vol.6, July 2008. 
14. Khan, N. \& Iqubal, M.A. (2009). Animal Husbandry Plays Significant Roles in Economic Viability of Marginal and Small Farmers in Aligarh District, Indian Farming, July 2009, pp.21-24

15. Khan, N. \& Parashari, A.K. (2019.) Livestock Production, Marketing and Future Prospects in India, Proceeding, The $8^{\text {th }}$ International Seminar on Tropical Animal Production, Prospects and Challenges for Sustainable Tropical Animal Production System, September, 23-25,2019, Yogyakarta, Indonesia.pp.32-44.

16. Khan, N. \& Parashari, A.K. (2018). Employment Generation Through Integrated Crop Livestock System in Bulandshahr District: A Geographical Analysis, ACTA Scientific Agriculture, vol.2, Issue 2, pp. 1-4

17. Khan, N. (2018). Integrated Livestock and Cropping System and Sustainable Rural Development in India: A case Study, Conference Proceeding Istanbul, August 16-17, 2018, pp. 1274-1280.

18. Kumar, A. et. al. (2018). Milk Farmers 'Choice of Marketing Channels in India, Economic \& Political Weekly, Review of Rural Affairs, Vol.53, No.51.

19. Kumar, S.S., Singh, R, Mishra, U.K., \& Mishra, D.J. (2012). Strategies for Sustainable Dairy Farming in India, A Review, Research Journal of Recent Sciences, vol.2, pp.4244.

20. Kurein, V. (2000). India's Milk Revolution" NFI Bulletin, A Bulletin of Nutritional foundation of India, Vol.21, No. 1, pp.1-5.

21. Livestock Census (2012). 19 th Livestock census 2019-All India Report, Department of Animal Husbandry and Dairying, Government of India.

22. Livestock Census (2019). 20 th Livestock census 2019-All India Report, Department of Animal Husbandry and Dairying, Government of India.

23. Mathur, B.N. (2000). Current Problems and Challenges Confronting the Dairy industry in India, Asia-Australia Journal of Animal Science, July 2000, pp.447-452

24. National Dairy Development Board, Annual Report (2018) Department of Animal Husbandry, Dairying, and Fisheries, Government of India.

25. Parida Y. \& Yadav D (2020). India's Dairy Sector Helped Lift the Rural Economy and Improve Livelihoods, Business Line, June 01, retrieved on 20 July,2020.

26. Ramarao, W.Y., Tiwari, S.P. \& Sigh, P. (2005). Crop Integrated Farming System for Augmenting Socio Economic Status of Small Holders Tribal Farmers of Chhattisgarh in Central India, Livestock Research Rural Development, Vol.17, No.8, pp.1-3.

27. Ramphal, O. (2016). Dairy Economy of India: Structural Changes in Consumption and Production, South Asia Research, Vol.27, no.2, pp.137-51.

28. Rangnekar, D.V. (2006). Livestock in Livelihood of Under Privileged Communities in India, A Review, International Livestock Research Institute (ILRI) Nairobi, Kenya.

29. Singh R.S. \& Shukla, N.S. (2017). Assessment Status of Dairying and Potential to Improve Socio economic Status of Milk Producers in Eastern Uttar Pradesh, Agro economic Research Centre, Allahabad.

30. Singh, R.B., Kaur, I., Singh, V.P. and Kaur, N. (2018). Factors Affecting Choice of Milk Marketing Channels by Dairy Farmers in Punjab, Journal of Kirishi Vigyan, Vol.6, No.2, pp.123-129.

31. Taneja, V.K. (2008). Semi Intensive and Intensive System: The Future, The Hindu Survey of Indian Agriculture.

32. Tekam D., Sonawane N., Bhanotra A. and Sawant M. (2019). Doubling of Farmers Income through Animal Husbandry by 2022, International Journal of Current Microbiology and Applied Sciences, Volume 8 Number 02, pp: 3246-3245.

33. The Hindu (2019). Dairy Farming Has Made Farmers Self Reliant, The Hindu, $01^{\text {st }}$ July 2020.

34. Uttar Pradesh Investor's Summit (2018). Dairy Nourishing Growth: UP Powering New India,21-23 February, http://www.udyogbandhu.com/, retrieved on 20 July 2020.

35. Vision 2022 (2018). National Action Plan for Dairy Development, Department of Animal Husbandry, Dairying and Fisheries, MAFW, Government of India. 